\title{
Effect of water temperature on reproductive development of Benedenia seriolae (Monogenea: Capsalidae) from Seriola lalandi in Australia
}

\author{
Julia A. Lackenby ${ }^{1,3, *}$, Clinton B. Chambers ${ }^{1,4}$, Ingo Ernst ${ }^{1,5}$, Ian D. Whittington ${ }^{1,2}$ \\ ${ }^{1}$ School of Earth and Environmental Sciences, Darling Building (DP418), University of Adelaide, North Terrace, \\ South Australia 5005, Australia \\ ${ }^{2}$ Monogenean Research Laboratory, Parasitology Section, South Australian Museum, North Terrace, \\ South Australia 5000, Australia \\ ${ }^{3}$ Present address: Faculty of Veterinary Science, University of Melbourne, 250 Princes Highway, Werribee, \\ Victoria 3030, Australia \\ ${ }^{4}$ Present address: Worley Parsons Komex, Environment and Water Resources, Level 3, QV1 Building, \\ 250 St Georges Terrace, Perth, Western Australia 6000, Australia \\ ${ }^{5}$ Present address: Aquatic Animal Health Unit, Product Integrity, Animal and Plant Health, Australian Government \\ Department of Agriculture, Fisheries and Forestry, GPO Box 858 Canberra, Australian Capital Territory 2601, Australia
}

\begin{abstract}
The monogenean Benedenia seriolae (Yamaguti, 1934) Meserve, 1938 is a major pathogen of farmed yellowtail kingfish Seriola lalandi in South Australia. To control parasite populations in commercial farms, an understanding of the effect of water temperature on parasite development is vital. This study investigated the effect of water temperature $\left(14,18,22\right.$ and $\left.26 \pm 0.5^{\circ} \mathrm{C}\right)$ on development, growth rates and age at sexual maturity of $B$. seriolae. Five distinct developmental stages, defined by the progressive development of reproductive organs, were used to describe development of $B$. seriolae from recently invaded larvae to sexually mature adults. Parasite age at the first sign of sexual maturity (ability to lay eggs) was strongly influenced by water temperature and was attained at $41,24,16$ and $14 \mathrm{~d}$ post infection (p.i.) at $14,18,22$ and $26 \pm 0.5^{\circ} \mathrm{C}$ respectively. Four parameters (parasite total length, maximum parasite width, accessory sclerite length and anterior hamulus length) were examined for suitability as an index of parasite age. Growth rates for each parameter increased with water temperature; however, mean anterior hamulus length was identified as the most reliable index of parasite age. Equations derived from these data can be used to estimate parasite age and time to sexual maturity at water temperatures ranging from 14 to $26^{\circ} \mathrm{C}$. The equations provide a simple tool to assist implementation of strategic treatment plans for $B$. seriolae infections in commercial kingfish farms, not only in South Australia but in other localities worldwide where $S$. lalandi is farmed.
\end{abstract}

KEY WORDS: Monogenea $\cdot$ Capsalidae Sea-cage aquaculture $\cdot$ Benedenia seriolae $\cdot$ Water temperature $\cdot$ Growth rates $\cdot$ Sexual maturity $\cdot$ Strategic treatment

\section{INTRODUCTION}

Marine finfish aquaculture is a fast-growing sector globally, responsible for high-value fish products. Pathogens can have expensive consequences for finfish farms, not only owing to their effect on fish health, reduced growth, marketability and even mortalities, but also to the increased labour and infrastructure costs necessary to manage infections. Monogeneans are significant parasites in Seriola spp. culture in Japan, New Zealand and Australia because they can proliferate rapidly due to their direct, single-host life cycle (Whittington 2005). In South Australia, 2 monogenean species are problematic in sea-cage culture of yellowtail kingfish Seriola lalandi: Zeuxapta seriolae (Heteraxinidae), a blood feeding polyopisthocotylean 
of the gills, and Benedenia seriolae (Capsalidae), a skin feeding monopisthocotylean parasitising the body surfaces. Information on egg laying, embryonation, hatching, parasite growth and development rates, especially age at sexual maturity, is vital for the development of strategies to manage and control parasite populations in farmed kingfish in sea-cages. Tubbs et al. (2005) determined the effect of temperature on in vitro fecundity, egg hatching and time to sexual maturity for $Z$. seriolae and $B$. seriolae from infected $S$. lalandi in New Zealand. Mooney et al. (2006) presented data for an in vivo egg laying rhythm in $Z$. seriolae from $S$. lalandi culture in South Australia. In the present study, we present in vivo data on the effect of water temperature on $B$. seriolae development, and determine the age at which sexual maturity is attained from experimental infections of $S$. lalandi. Experiments were run at $14,18,22$ and $26 \pm 0.5^{\circ} \mathrm{C}$ to represent local water temperatures that farmed $S$. lalandi experience in Spencer Gulf, South Australia. We discuss the application of these data to the effective management of B. seriolae infections in S. lalandi farms in South Australia.

\section{MATERIALS AND METHODS}

Source of fish. In February 2004, 84 Seriola lalandi (weight range: 80 to $200 \mathrm{~g}$; fork length range: 18 to $22 \mathrm{~cm}$ ) from a commercial fish farm near Whyalla, Spencer Gulf, South Australia, were transported to the South Australian Aquatic Sciences Centre (SAASC), Adelaide. Until September 2004, fish were maintained in a $2100 \mathrm{l}$ flow-through tank at $16^{\circ} \mathrm{C}$ and fed daily on a commercial kingfish diet $(3 \mathrm{~mm}$ Skretting classic HS). During September 2004, fish were transferred to a $2100 \mathrm{l}$ flow-through tank at ambient temperature (approximately $21^{\circ} \mathrm{C}$ ) and fed daily. Four days before infection with Benedenia seriolae larvae (see below), groups of approximately 40 fish were bathed in $160 \mathrm{l}$ of dechlorinated tap water for $5 \mathrm{~min}$ to ensure they were free of any existing $B$. seriolae infection (Chambers \& Ernst 2005). After bathing, 43 and 41 fish were transferred into 2 separate temperature-controlled, flowthrough tanks containing $600 \mathrm{l}$ of seawater (salinity $41 \mathrm{ppt}$, flow rate $1200 \mathrm{l} \mathrm{h}^{-1}$ with continual aeration) for $4 \mathrm{~d}$ acclimation before experimental infection.

Water temperatures of $14,18,22$ and $26^{\circ} \mathrm{C}$ were selected to represent the annual temperature range experienced by farmed Seriola lalandi in Spencer Gulf, South Australia (where, however, water temperatures may drop below $14^{\circ} \mathrm{C}$ for periods in winter). To avoid cross contamination between adjacent tanks in concurrent experiments, separate equipment was used for each experimental tank. After each sampling event, all bathing tanks, nets and filters were cleaned thoroughly with hot tap water and left to air dry to kill any Benedenia seriolae eggs (Ernst et al. 2005). To prevent water transfer between tanks from fish splashing during feeding, plastic curtains were erected to isolate adjacent tanks. Water temperature $\pm 0.5^{\circ} \mathrm{C}$ of the target temperature was maintained via water inflow from the SAASC system and was measured in each tank every minute using a 4-channel data-logging thermometer (Sper Scientific).

Initial source of parasites. Using fine forceps, approximately 400 live, adult Benedenia seriolae were carefully removed from the skin of several infected Seriola lalandi at a commercial farm near Whyalla, Spencer Gulf, South Australia. Parasites were transferred into $250 \mathrm{ml}$ plastic jars containing approximately $100 \mathrm{ml}$ of Millipore filtered $(0.2 \mu \mathrm{m})$ seawater (FSW, salinity $41 \mathrm{ppt}$ ) and maintained at $20 \pm 1^{\circ} \mathrm{C}$ during the $5 \mathrm{~h}$ journey to SAASC, during which time approximately 15300 eggs ( 7.65 eggs parasite $\left.{ }^{-1} \mathrm{~h}^{-1}\right)$ were laid in vitro.

Experimental infections. Eggs laid in vitro were incubated in small Perspex wells (1 ml volume, internal diameter 9 mm, see Kearn 1973) immersed in a glass dish (volume $30 \mathrm{ml}, 4 \mathrm{~cm}$ diameter, $3 \mathrm{~cm}$ depth) containing filtered seawater (FSW) at $20 \pm 0.1^{\circ} \mathrm{C}$ and exposed to a 12:12 $\mathrm{h}$ light:dark regime (light on 06:00 h, light off 18:00 h). Each dish was sealed with a glass plate and water changes were made twice daily. After $7 \mathrm{~d}$, glass plates were removed and wells containing hatching eggs were transferred to plastic infection chambers (250 ml, $9 \mathrm{~cm}$ diameter, $5 \mathrm{~cm}$ depth) filled with FSW and fitted with a $105 \mu \mathrm{m}$ nylon mesh lid. Kearn et al. (1992a) demonstrated that Benedenia seriolae eggs hatch during daylight, so infection chambers were placed in the 2 temperature controlled tanks containing experimental unparasitised fish during the hours $06: 00$ to $12: 00 \mathrm{~h}$, at which time water flow to tanks was suspended. Infection chambers prevented escape of eggs into tanks while allowing hatched larvae to swim freely into the tank containing unparasitised fish. After the $6 \mathrm{~h}$ infection period, chambers were removed from the tank and their contents preserved in $1 \%$ formalin. Egg wells were examined for empty eggs using a stereomicroscope to ensure that hatching had occurred.

Due to the expected influence of water temperature on parasite growth, different numbers of fish were required at each temperature: 43 fish at $14^{\circ} \mathrm{C}, 41$ fish at $18^{\circ} \mathrm{C}, 35$ fish at $22^{\circ} \mathrm{C}$ and 30 fish at $26^{\circ} \mathrm{C}$. Experiments at $14^{\circ} \mathrm{C}$ and $18^{\circ} \mathrm{C}$ were run concurrently with sampled fish returned to a separate, parasite-free holding tank. At the conclusion of the $14^{\circ} \mathrm{C}$ experiment, the tank temperature was raised to $22^{\circ} \mathrm{C}$ and previously sampled fish were cleaned again and experimentally re- 
infected in this tank, as described above. The $26^{\circ} \mathrm{C}$ experiment commenced at the conclusion of the $18^{\circ} \mathrm{C}$ experiment, using the same fish population.

Effect of water temperature on parasite growth. At each temperature, fish were sampled and parasites removed at regular intervals post infection (p.i.): 1 fish was sampled every $3 \mathrm{~d}$ at 14 and $18^{\circ} \mathrm{C}$, every $2 \mathrm{~d}$ at $22^{\circ} \mathrm{C}$ and daily at $26^{\circ} \mathrm{C}$. Sampling began $1 \mathrm{~d}$ p.i.. Fish were anaesthetised in separate 601 tanks $(600 \times 360 \times$ $260 \mathrm{~mm}$ ) containing $0.6 \mathrm{ml}$ clove oil in $30 \mathrm{l}$ of seawater filtered through a $75 \mu \mathrm{m}$ mesh, then transferred by hand to a second 601 tank containing $30 \mathrm{l}$ of dechlorinated tap water for $5 \mathrm{~min}$ to kill Benedenia seriolae infecting fish (Chambers \& Ernst 2005). Any parasites remaining attached to fish were removed by gently rubbing fish skin surfaces by hand. Older (i.e. larger) worms were gently removed using fine forceps. Water from the anaesthetic and tap water bathing tanks was filtered using a $75 \mu \mathrm{m}$ mesh filter, back-flushed into a $250 \mathrm{ml}$ sample jar, and the contents were preserved in $1 \%$ formalin. Low formalin concentrations were sufficient to preserve parasites owing to the low tissue/ fixative ratio. Parasite numbers per sampled fish were counted within $24 \mathrm{~h}$ and all specimens were stained with Mayer's haematoxylin, dehydrated in an ethanol series, cleared in cedar wood oil and mounted in Canada balsam. Parasite total length (parasite TL, including the haptor), maximum parasite width, accessory sclerite length and anterior hamulus length were measured (Fig. 1) using a computerised digitising system as described by Roff \& Hopcroft (1986). Posterior hamulus length was not measured because these haptoral sclerites were difficult to locate in older (larger) parasites.

Determination of age at sexual maturity. Parasite age at sexual maturity was determined at each water temperature by assessing the development of male and female organs and the presence of eggs in the female reproductive system of mounted specimens. Organs assessed were testes, male copulatory organ and vas deferens (male) and ovary, ootype, uterus, vitellarium and vitelline reservoir (female). At $28^{\circ} \mathrm{C}$, Benedenia seriolae may reach sexual maturity at a parasite TL of approximately $4 \mathrm{~mm}$ (I. Ernst \& I.D. Whittington unpubl. data). Therefore, when parasite TL in samples approached $3.5 \mathrm{~mm}$ and reproductive organs neared full development, the sampling rate was increased to 1 fish per day to determine the day on which eggs were first produced. A single fish at each temperature was randomly selected, isolated for $1 \mathrm{~h}$ in a 601 tank containing $30 \mathrm{l}$ of filtered, aerated seawater and sampled as above to obtain total parasite numbers, parasite morphometric and developmental data. Isolation tank water was filtered, as described previously, to determine whether $B$. seriolae eggs were present.

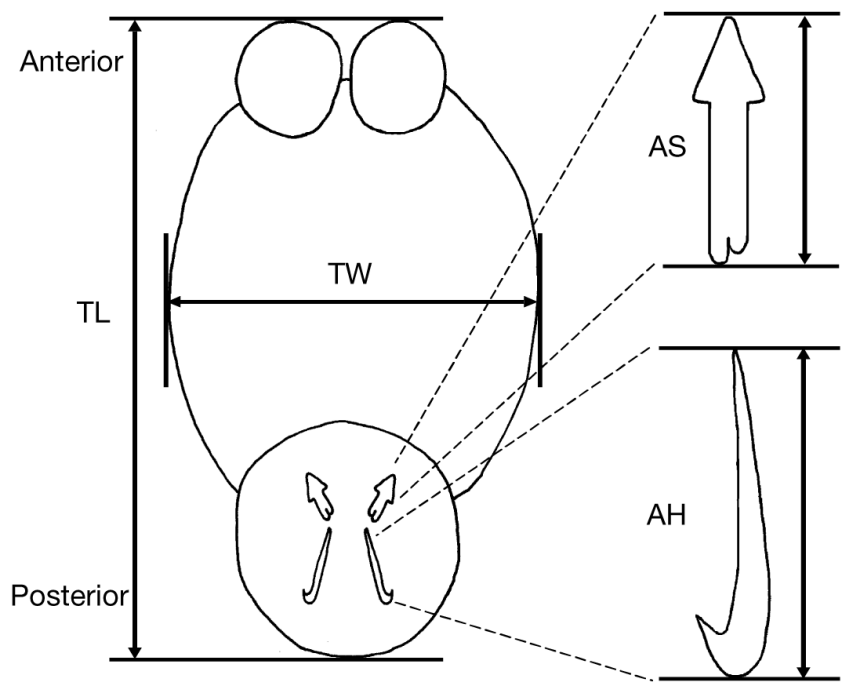

Fig. 1. Benedenia seriolae. Morphometric parameters: TL, parasite total length (including haptor); TW, maximum parasite width; AS, accessory sclerite length measured from distal point to longest bifid extremity; $\mathrm{AH}$, anterior hamulus length. Posterior hamuli (not drawn) were not measured owing to difficulty in locating them in older (larger) specimens

Attainment of sexual maturity was confirmed by the first sign of eggs either in tank filtrate or in the female reproductive system of mounted parasites.

Analysis. The relationship between water temperature and parasite age was plotted for all 4 parasite morphometric parameters at each experimental temperature and analysed using 1-way ANOVA, and the $F$-ratio was used to determine the significance of the test.

\section{RESULTS}

\section{Stages of development for Benedenia seriolae}

Five developmental stages were assigned to Benedenia seriolae based on the successive appearance of reproductive organs (Fig. 2). Development was protandrous with male organs developing first (Fig. 2A-C) followed by female organs (Fig. 2C-E). A detailed developmental sequence based on 14 specimens per stage at $18^{\circ} \mathrm{C}$, including the total length range for each developmental stage from post larva to sexually mature adult, is shown in Fig. 2. The presence of eggs either in the ootype of mounted specimens or in seawater containing isolated, experimentally infected fish (see below) confirmed the attainment of sexual maturity (Stage 5, see Fig. 2E). Regardless of water temperature $\left(14,18,22\right.$ and $\left.26 \pm 0.5^{\circ} \mathrm{C}\right)$, sexual maturity of $B$. seriolae was attained at a similar mean parasite TL $(3.9 \mathrm{~mm} \pm \mathrm{SE} 7.46 \mu \mathrm{m})$. 


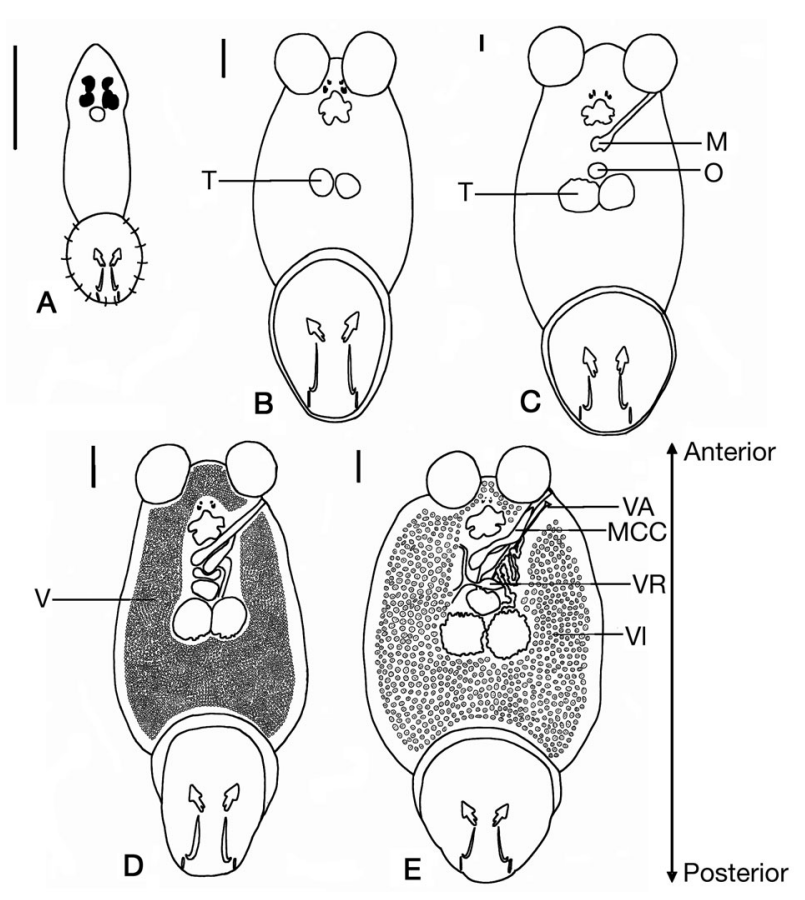

Fig. 2. Benedenia seriolae. Successive developmental stages based on 14 specimens per stage at $18 \pm 0.5^{\circ} \mathrm{C}$. (A) Undifferentiated post larva; no reproductive organs (TL: $0.26-$ $1.0 \mathrm{~mm}$ ). (B) Appearance of testes (T); no female reproductive organs (TL: 1.1-2.1 mm). (C) Further development of testes, male copulatory organ (M) and appearance of ovary (O) (TL: $2.2-2.8 \mathrm{~mm}$ ). (D) Male reproductive system (testes, male copulatory organ, vas deferens) fully developed; further ovarian development; appearance of compact vitelline follicles (V) (TL: $2.9-3.8 \mathrm{~mm}$ ). (E) Sexually mature specimen with functional vitellarium able to lay eggs; male copulatory complex (MCC), vagina (VA), vitellarium (Vl) and vitelline reservoir (VR) (TL: $>3.9 \mathrm{~mm})$. Regardless of water temperature $(14,18$, 22 and $26 \pm 0.5^{\circ} \mathrm{C}$ ), sexual maturity was attained at a similar mean parasite TL $(3.9 \mathrm{~mm} \pm \mathrm{SE} 7.46 \mu \mathrm{m})$ and a similar mean anterior hamulus length $(292.5 \pm \mathrm{SE} 0.236 \mu \mathrm{m})$. Scale bars $(\mathrm{A}-\mathrm{C})=100 \mu \mathrm{m}_{i}(\mathrm{D}-\mathrm{E})=50 \mu \mathrm{m}$

\section{Effect of water temperature on parasite growth rates}

Experiments continued for the following durations: $76,45,26$ and $24 \mathrm{~d}$ p.i. at $14,18,22$ and $26 \pm 0.5^{\circ} \mathrm{C}$, respectively. Time to attain sexual maturity was determined from a range of 4 to 17 Benedenia seriolae specimens removed from single isolated fish specimens at each water temperature, when freely deposited eggs were first detected in isolation tank filtrate or eggs were observed in the female reproductive system in mounted parasites. Parasite age at the first sign of sexual maturity was strongly influenced by water temperature and was attained at 41, 24, 16 and $14 \mathrm{~d}$ p.i. at 14, 18, 22 and $26 \pm 0.5^{\circ} \mathrm{C}$, respectively (Fig. 3). Means of parasite TL, maximum parasite width, accessory sclerite length and anterior hamulus length from parasite samples were used to assess parasite growth

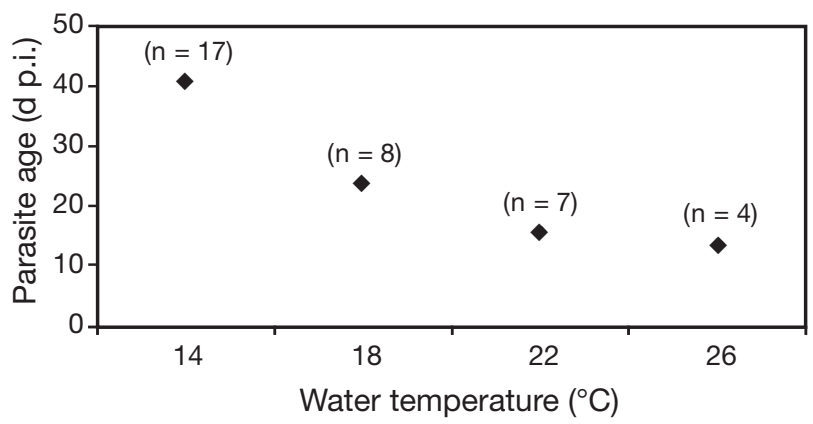

Fig. 3. Benedenia seriolae. Relationship between age (d p.i.) at sexual maturity (onset of egg production) and water temperatures between 14 and $26 \pm 0.5^{\circ} \mathrm{C}$, determined from parasite populations of single fish specimens isolated to assess the first sign of parasite eggs in tank filtrate or in the female reproductive system of mounted specimens; n, no. of parasites recovered from experimental fish at each water temperature

at different times p.i. at each water temperature (Fig. 4A-D, respectively). All parameters measured indicate that parasite growth was continuous for the duration of the experiments, with steeper slopes indicating faster growth at higher water temperatures (Fig. 4). Plots of mean parasite TL, mean maximum parasite width and mean accessory sclerite length against parasite age were statistically linear (Fig. 4A-C, respectively, $\mathrm{p}<0.001$ ); however, the plot of mean anterior hamulus length versus parasite age (Fig. 4D) demonstrated the best fit to a linear relationship at each temperature (as determined by $\mathrm{R}^{2}$ values). Therefore, anterior hamulus length $\left(\mathrm{R}^{2}=0.98\right)$ displayed near-constant growth rates at each experimental temperature. Of the parameters measured, anterior hamulus length was considered the most reliable index of parasite age, not only because of a near-constant growth rate, but also because of the relative ease with which these large haptoral sclerites can be identified and measured. Furthermore, the anterior hamuli comprise hard sclerotised protein, which, unlike soft body tissues, are affected less by fixation and preparation methods.

\section{Application of these data}

After establishing experimentally that mean anterior hamulus length in Benedenia seriolae is a useful and reliable indicator of parasite age, data were inverted to generate an anterior hamulus growth index (AHGI) in terms of time per unit length $\left(\mathrm{d} \mathrm{\mu m}^{-1}\right.$; Fig. 5). This is a significant relationship $\left(\mathrm{R}^{2}=0.9999 ;\right.$ F-ratio from 1 -way ANOVA = 591866.99) and the curve in Fig. 5 is described by the following quadratic equation (where $T=$ water temperature):

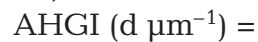

$$
0.500263-0.0367877 T+0.00074666 T^{2}
$$




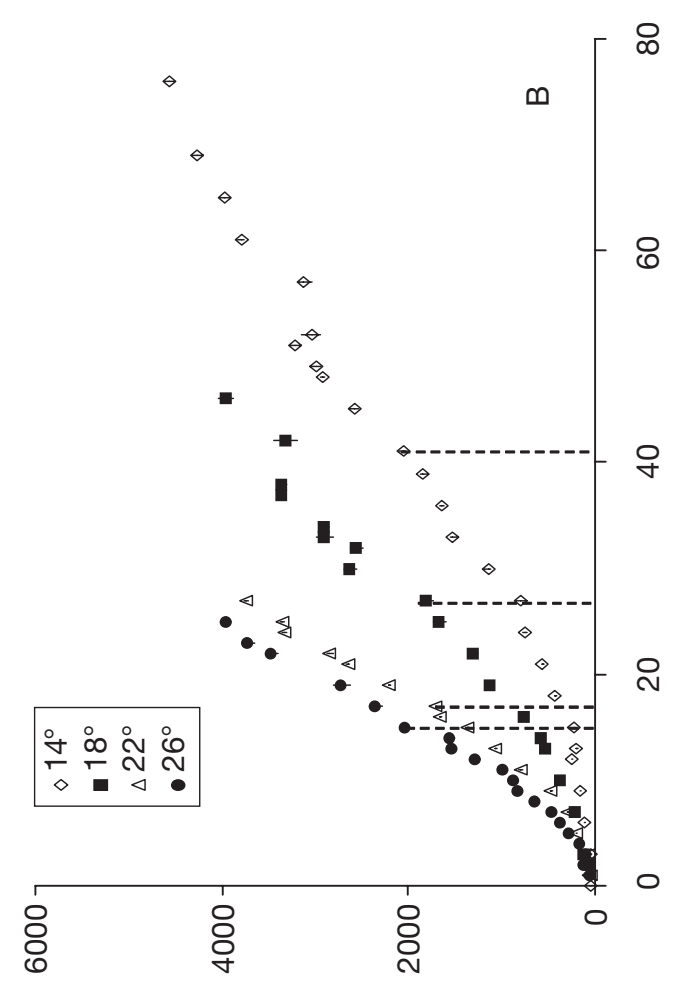

(ur) чұр!̣ әң!seıed unu!̣em uеәW

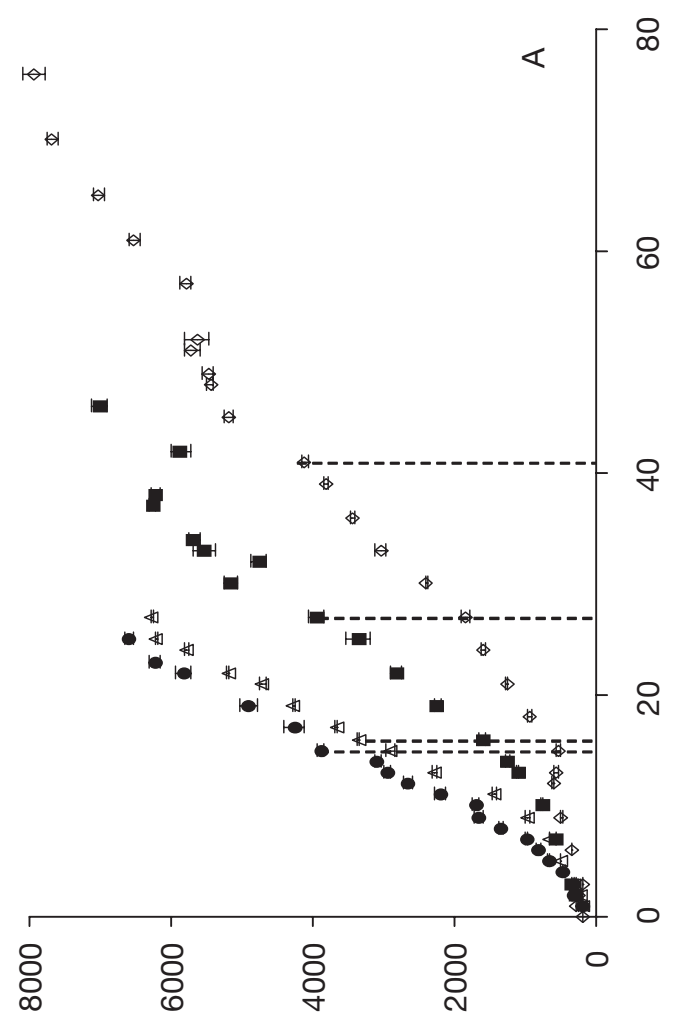

(url) чұбиә әң!sexed ןеңоғ иеәW

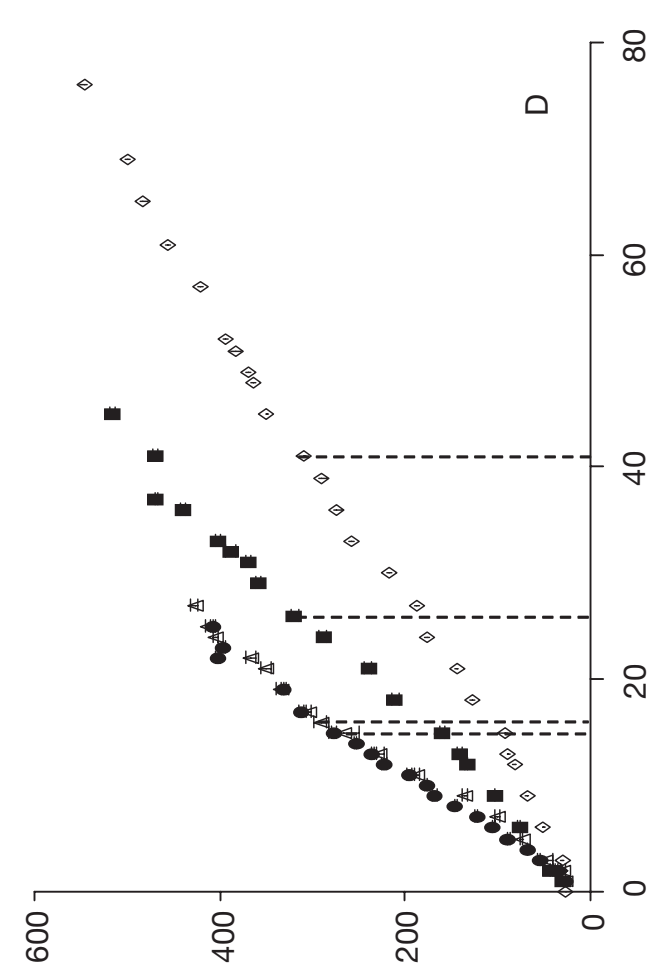

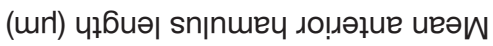

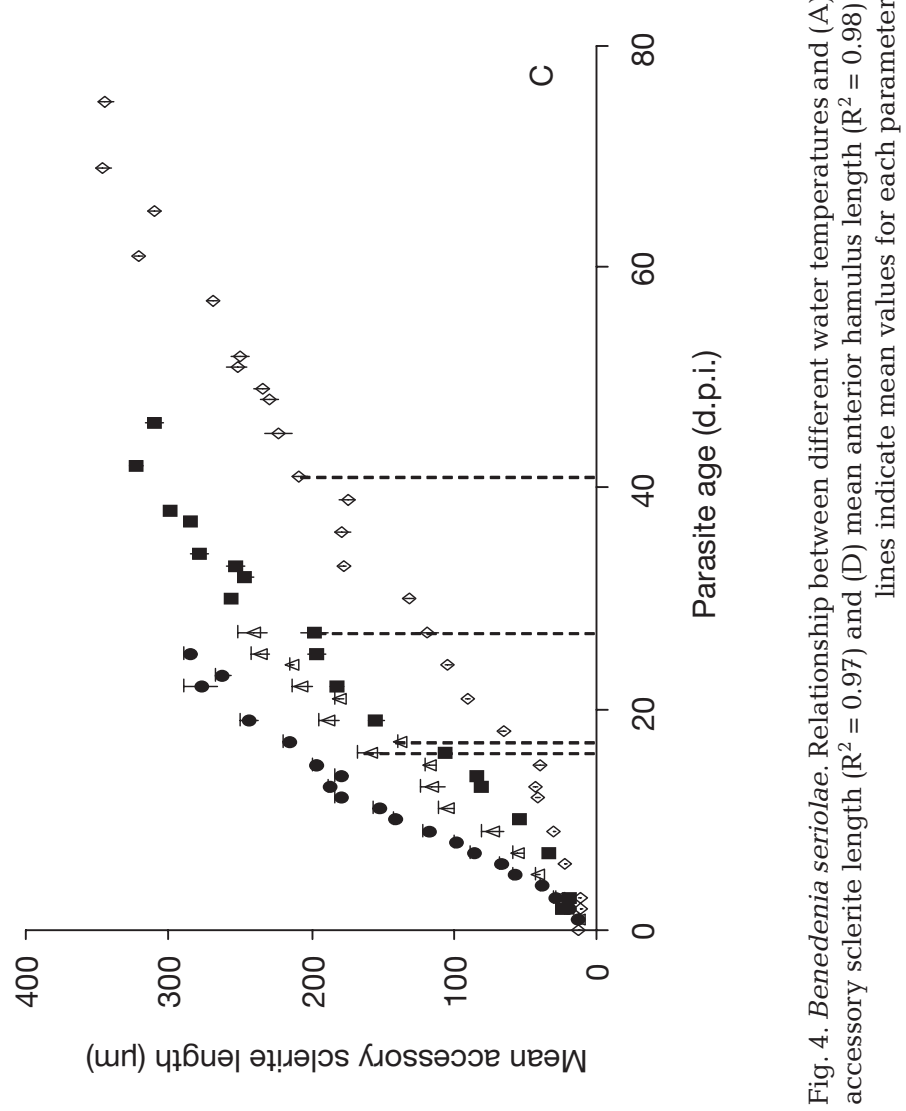




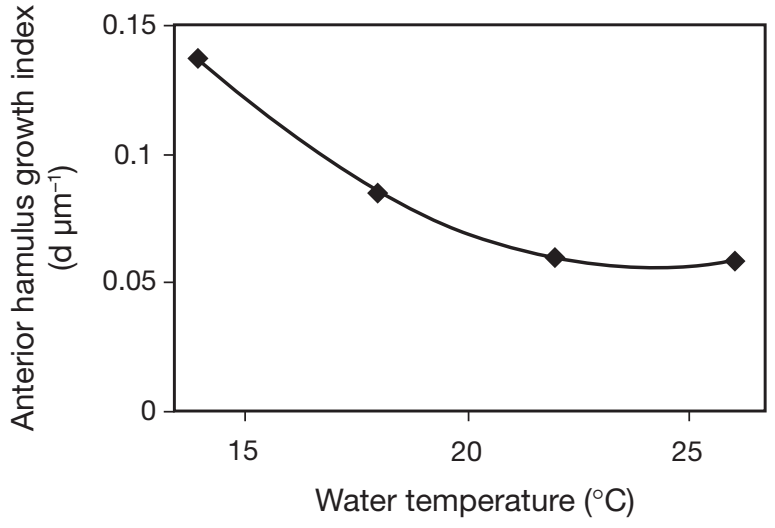

Fig. 5. Benedenia seriolae. Mean anterior hamulus growth index (AHGI) $\left(\mathrm{d} \mathrm{um}^{-1}\right)$ for water temperatures between 14 and $26 \pm 0.5^{\circ} \mathrm{C}$, derived from inverting mean anterior hamulus length at sexual maturity for each water tempera-

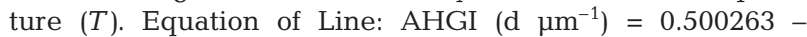
$0.0367877 T+0.00074666 T^{2} \quad(1$-way ANOVA, F-ratio $=$ 591866.99; $\left.\mathrm{R}^{2}=0.9999\right)$

This relationship allows current parasite age to be determined using information about mean anterior hamulus length at a known water temperature between 14 and $26^{\circ} \mathrm{C}$. Therefore:

current parasite age $(d$ p.i. $)=$ mean anterior hamulus length $\times$ AHGI

Mean anterior hamulus length at sexual maturity at all water temperatures was $292.5 \pm \mathrm{SE} 0.236 \mu \mathrm{m}$ and is termed the 'anterior hamulus length at sexual maturity constant'. Applying these data for water temperatures between 14 and $26^{\circ} \mathrm{C}$ :

parasite age at sexual maturity $(\mathrm{d}$ p.i.) $=$ $292.5 \mu \mathrm{m} \times$ AHGI (at $T$ of interest)

These equations can be used to calculate current parasite age for Benedenia seriolae on a population of captive Seriola lalandi and to estimate parasite age at sexual maturity at the temperature at which fish are being farmed. The benefits and application of these data are discussed below.

\section{DISCUSSION}

Benedenia seriolae is a serious problem in Seriola spp. aquaculture in Japan (Hoshina 1968, Egusa 1983, Ogawa \& Yokoyama 1998) owing to its direct effects on fish health and indirect effects on farm efficiency. The parasite is equally problematic for the emerging Seriola lalandi industry in South Australia (Ernst et al. 2002) but, despite its commercial impact, there is limited knowledge of the parameters of the $B$. seriolae life cycle. A thorough understanding of these life cycle parameters and how they are affected by environmental variables (e.g. temperature) is required for effective parasite management. Temperature is known to be a key variable effecting the life cycle parameters of capsalid parasites (Ernst \& Whittington 1996, Ernst et al. 2005, Tubbs et al. 2005) and these effects must be understood if management strategies that effectively interrupt parasite life cycles are to be developed.

Previous studies of relevant capsalid biology have focused on close relatives of Benedenia seriolae, such as Entobdella soleae (see Kearn 1990), Neobenedenia girellae (see Bondad-Reantaso et al. 1995) and Benedenia hoshinai (see Ogawa 1984). Comparisons are often made among these species owing to broad similarities in morphology, systematic position and assumed similarities in parasite biology. Previous studies of life cycle parameters of $B$. seriolae have examined specimens of Seriola quinqueradiata from Japan (Kearn et al. 1992b) and S. lalandi from New Zealand (Tubbs et al. 2005). The present study describes life cycle parameters of $B$. seriolae from $S$. lalandi at water temperatures and salinity experienced by parasites and hosts in sea-cage farms in Spencer Gulf, South Australia. Data were generated on the effect of water temperature on parasite growth rate, the development of reproductive organs, age at sexual maturity and the most suitable morphometric feature for estimating parasite age. The data were used to develop criteria for determining sexual maturity of $B$. seriolae and to develop a growth index for estimating parasite age. Our findings will assist $S$. lalandi farmers to evaluate the population parameters (e.g. current parasite age, estimated age at maturity) of parasites infecting farmed fish populations, and permit refinement of whole-farm parasite management strategies.

As reported by Kearn et al. (1992b) for Benedenia seriolae from Seriola quinqueradiata in Japan and by Tubbs et al. (2005) for B. seriolae from $S$. lalandi in New Zealand, we found that the reproductive development of $B$. seriolae from $S$. lalandi is protandrous (Fig. 2). Several studies have confirmed protandry among the Capsalidae, including those of Ogawa (1984) on B. hoshinai and Whittington \& Ernst (2002) on $B$. lutjani. The 5 stages reported here can be used to describe parasite development. Sexual maturity was determined based on the first appearance of a functional vitellarium, the presence of eggs in the female reproductive system and/or detection of laid eggs in tank filtrate. Accurate determination of sexual maturity is especially important for parasite management on commercial farms because effective parasite control requires knowledge of the age at which reinfecting parasites (following previous treatment of fish) first begin to lay eggs. This knowledge allows scheduling of treatments to break the parasite life cycle by killing 
developing parasites before they can mature and lay eggs (which cannot be controlled or treated). We found that age at sexual maturity for $B$. seriolae is temperature dependent (Fig. 3).

The growth rates of all measured morphometric parameters (mean parasite $\mathrm{TL}$, mean maximum parasite width, mean accessory sclerite length and mean anterior hamulus length) were temperature dependent. Parasites grew faster at higher temperatures, with continual growth of all parameters observed throughout experiments at each water temperature. We found that parasite TL and maximum parasite width may not be a reliable indicator of parasite age owing to variability resulting from specimen processing techniques, such as compression that can affect linear measurements of soft body tissues. Other, more reliable parameters include accessory sclerite length and anterior hamulus length because these hard sclerotised structures are less affected by fixation methods. Mean anterior hamulus length showed the best fit to a linear relationship with increasing parasite age (Fig. 4). These sclerites can be measured in situ with ease (Figs. 1 \& 2) and therefore are the best parameter by which to estimate the age of Benedenia seriolae.

Kearn (1990) determined that a logarithmic relationship existed between anterior hamulus length and parasite age in Entobdella soleae, and concluded that continual and logarithmic growth throughout its life meant anterior hamulus length was the best index of parasite age. This was confirmed by Ogawa (1984) and by Whittington \& Ernst (2002) for the capsalids Benedenia hoshinai and B. lutjani, respectively. Kearn's (1990) experiment ran over a far longer period, $185 \mathrm{~d}$ p.i. at $12^{\circ} \mathrm{C}$, than the studies of Ogawa (1984) and Whittington \& Ernst (2002), and included the life span of E. soleae. Our results confirm that mean anterior hamulus length is also the most reliable parameter for estimating the age of $B$. seriolae. It was beyond the scope of this study to determine the longevity of $B$. seriolae; however, the oldest parasites recovered were $76 \mathrm{~d}$ p.i. at $14^{\circ} \mathrm{C}$, and at this age, growth remained linear for all morphometric parameters (Fig. 4).

Using information on the parasite growth relationships presented in this study, parasite age and the age at which parasites will become sexually mature (for a given water temperature) can be estimated. To estimate parasite age: (1) use Eq. 1 to determine the AHGI for Benedenia seriolae at a given water temperature and (2) enter AHGI (as calculated above) and mean anterior hamulus length for the specimens under study into Eq. 2. If the oldest sampled parasites are juveniles, the age at which they will become sexually mature (commence laying eggs) can be estimated by entering the AHGI for the given water temperature into Eq. 3. By determining current parasite age and the predicted age at which parasites will mature, parasite treatment can be timed to occur before developing parasites mature and begin to lay eggs. The data used to develop these equations were derived from parasite populations on Seriola lalandi from the Spencer Gulf and with water quality conditions experienced in the area. Although these equations may be applicable elsewhere, differing conditions (e.g. Spencer Gulf is more saline than oceanic seawater) and different host fish species may have to be considered when applying the equations presented here to different regions and host species.

In South Australia, Benedenia seriolae infections on farmed Seriola lalandi are controlled by bath treatments using hydrogen peroxide (Chambers \& Ernst 2005). These treatments are highly effective at killing the juvenile and adult worms that parasitise sea-caged $S$. lalandi; however, reinfection may occur rapidly after treatment by larvae already in the water column as well as by larvae that continue to hatch from embryonating eggs in the environment near sea-cages. To control reinfection and interrupt the parasite's life cycle, treatments should be coordinated spatially and temporally. Chambers \& Ernst (2005) discussed the spatial coordination required for managing $B$. seriolae on farmed $S$. lalandi in the Spencer Gulf. In the current study we presented data that will permit improved temporal coordination of treatments. Egg embryonation times for $B$. seriolae have been studied at many water temperatures and from 2 host species (see Hoshina 1968, Ernst et al. 2005, Tubbs et al. 2005). This information is necessary to determine when reinfection from embryonating eggs in the environment will occur following an initial round of spatially coordinated treatments. Subsequent treatments should be coordinated temporally to occur after all parasite eggs in the area have hatched but before the first reinfecting parasites reach sexual maturity. Our data will assist this temporal coordination by allowing current parasite age and age at maturity to be estimated at different environmental temperatures.

Acknowledgements. We thank South Australian Aquaculture Management for supplying fish and parasites and the South Australian Aquatic Sciences Centre, West Beach, for access to and use of their facilities. We also thank A. Mooney (University of Adelaide) for assistance with experimentation and Dr. A. Munro (University of Adelaide) for help with statistical issues. This study was conducted as part of the Yellowtail and Kingfish Parasite Management Project, funded by an Australian Research Council grant (LP0211375; 2002-2005) awarded to I.D.W. and I.E. and supported by industry partners Yamaha Nutreco Aquatech, Skretting Australia and the South Australian Marine Finfish Farmers Association. We also acknowledge the support of the School of Earth and Environmental Sciences, University of Adelaide, for facilities and support to J.A.L. during her Honours degree. 


\section{LITERATURE CITED}

Bondad-Reantaso MG, Ogawa K, Fukudome M, Wakabayashi H (1995) Reproduction and growth of Neobenedenia girellae (Monogenea, Capsalidae), a skin parasite of cultured marine fishes of Japan. Fish Pathol 30:227-231

Chambers CB, Ernst I (2005) Dispersal of the skin fluke Benedenia seriolae (Monogenea: Capsalidae) by tidal currents and implications for sea cage farming of Seriola spp. Aquaculture 250:60-69

Egusa S (1983) Disease problems in Japanese yellowtail, Seriola quinqueradiata, culture: a review. Rapp P-V Reun Cons Int Explor Mer 182:10-18

Ernst I, Whittington ID (1996) Hatching rhythms in the capsalid monogeneans Benedenia lutjani from the skin and B. rohdei from the gills of Lutjanus carpontatus at Heron Island, Queensland, Australia. Int J Parasitol 26: 1191-1204

Ernst I, Whittington ID, Corneillie S, Talbot C (2002) Monogenean parasites in sea-cage aquaculture. Austasia Aquac Feb/Mar:46-48

Ernst I, Whittington ID, Corneillie S, Talbot C (2005) Effects of temperature, salinity, desiccation and chemical treatments on egg embryonation and hatching success of Benedenia seriolae (Monogenea: Capsalidae), a parasite of farmed Seriola spp. J Fish Dis 28:157-164

Hoshina T (1968) On the monogenetic trematode, Benedenia seriolae, parasitic on yellow-tail, Seriola quinqueradiata. Bull Off Int Epizoot 69:1179-1191

Kearn GC (1973) The endogenous circadian hatching rhythm in the monogenean parasite Entobdella soleae, and its relationship to the activity rhythm of the host (Solea solea). Parasitology 66:101-122

Kearn GC (1990) The rate of development and longevity of

Editorial responsibility: Robin Overstreet,

Ocean Springs, Mississippi, USA the monogenean skin parasite Entobdella soleae. J Helminthol 64:340-342

Kearn GC, Ogawa K, Maeno Y (1992a) Hatching patterns of the monogenean parasites Benedenia seriolae and Heteraxine heterocerca from the skin and gills respectively, of the same host fish, Seriola quinqueradiata. Zool Sci 9:451-455

Kearn GC, Ogawa K, Maeno Y (1992b) Egg production, the oncomiracidium and larval development of Benedenia seriolae, a skin parasite of the yellowtail Seriola quinqueradiata, in Japan. Publ Seto Mar Biol Lab 35:351-362

Mooney AJ, Ernst I, Whittington ID (2006) An egg-laying rhythm in Zeuxapta seriolae (Monogenea: Heteraxinidae), a gill parasite of yellowtail kingfish (Seriola lalandi). Aquaculture 253:10-16

Ogawa K (1984) Development of Benedenia hoshinai (Monogenea) with some notes on its occurrence on the host. Bull Jpn Soc Sci Fish 50:2005-2011

Ogawa K, Yokoyama H (1998) Parasitic diseases of cultured marine fish in Japan. Fish Pathol 33:303-309

Roff JC, Hopcroft RR (1986) High precision micro-computer based measuring system for ecological research. Can J Fish Aquat Sci 43:2044-2048

Tubbs LA, Poortenaar CW, Sewell MA, Diggles BK (2005) Effects of temperature on fecundity in vitro, egg hatching and reproductive development of Benedenia seriolae and Zeuxapta seriolae (Monogenea) parasitic on yellowtail kingfish Seriola lalandi. Int J Parasitol 35:315-327

Whittington ID (2005) Monogenea Monopisthocotylea (ectoparasitic flukes). In: Rohde K (ed) Marine parasitology. CSIRO Publishing, Melbourne

Whittington ID, Ernst I (2002) Migration, site-specificity and development of Benedenia lutjani (Monogenea: Capsalidae) on the surface of its host, Lutjanus carponotatus (Pisces: Lutjanidae). Parasitology 124:423-434

Submitted: July 25, 2006; Accepted: December 7, 2006

Proofs received from author(s): March 6, 2007 